\title{
Shade induced changes in biomechanical petiole properties in the stoloniferous herb Trifolium repens
}

\author{
Heidrun Huber · Jan de Brouwer · Hannie de Caluwe • \\ Jelmer Weijschedé · Niels P. R. Anten
}

Published online: 6 December 2007

(C) Springer Science+Business Media B.V. 2007

\section{Erratum to: Evol Ecol \\ DOI 10.1007/s10682-007-9204-6}

The name of the 4th author is misspelled (Weijschedé instead of Wijschedé)

In the references section Weijschedé et al 2008 should be Weijschedé J, Antonise K, de Caluwe H, de Kroon H, Huber H (2008) The role of cell number and cell length on petiole length and shade-induced elongation in Trifolium repens. Am J Bot (in press).

The online version of the original article can be found under doi:10.1007/s10682-007-9204-6.

H. Huber $(\bowtie) \cdot$ J. de Brouwer $\cdot$ H. de Caluwe $\cdot$ J. Weijschedé

Department of Ecology, IWWR, Radboud University Nijmegen, Toernooiveld 1, Nijmegen 6525 ED, The Netherlands

e-mail: H.Huber@science.ru.nl

N. P. R. Anten

Section of Plant Ecology and Biodiversity, Institute of Environmental Biology, Utrecht University, P.O. Box 800.84, Utrecht 3508 TB, The Netherlands 